\title{
Reinduction of ErbB2 in astrocytes promotes radial glial progenitor identity in adult cerebral cortex
}

\author{
H.T. Ghashghaei, ${ }^{1,2}$ Jill M. Weimer, ${ }^{1}$ Ralf S. Schmid, ${ }^{1,3}$ Yukako Yokota, ${ }^{1}$ Ken D. McCarthy, ${ }^{4}$ \\ Brian Popko, ${ }^{5}$ and E.S. Anton ${ }^{1,6}$ \\ ${ }^{1}$ University of North Carolina Neuroscience Center and the Department of Cell and Molecular Physiology, The University \\ of North Carolina School of Medicine, Chapel Hill, North Carolina 27599, USA; ${ }^{2}$ Department of Molecular Biomedical \\ Sciences, School of Veterinary Medicine, North Carolina State University, Raleigh, North Carolina 27607 , USA; ${ }^{3}$ Center for \\ Drug Discovery and Department of Neurobiology, Duke University Medical Center, Durham, North Carolina 27704, USA; \\ ${ }^{4}$ Department of Pharmacology, The University of North Carolina School of Medicine, Chapel Hill, North Carolina 27599, \\ USA; ${ }^{5}$ The Jack Miller Center for Peripheral Neuropathy, Department of Neurology, The University of Chicago, \\ Chicago, Illinois 60637, USA
}

Radial glial cells play a critical role in the construction of mammalian brain by functioning as a source of new neurons and by providing a scaffold for radial migration of new neurons to their target locations. Radial glia transform into astrocytes at the end of embryonic development. Strategies to promote functional recovery in the injured adult brain depend on the generation of new neurons and the appropriate guidance of these neurons to where they are needed, two critical functions of radial glia. Thus, the competence to regain radial glial identity in the adult brain is of significance for the ability to promote functional repair via neurogenesis and targeted neuronal migration in the mature brain. Here we show that the in vivo induction of the tyrosine kinase receptor, ErbB2, in mature astrocytes enables a subset of them to regain radial glial identity in the mature cerebral cortex. These new radial glial progenitors are capable of giving rise to new neurons and can support neuronal migration. These studies indicate that ErbB2 signaling critically modulates the functional state of radial glia, and induction of ErbB2 in distinct adult astrocytes can promote radial glial identity in the mature cerebral cortex.

[Keywords: Cortical development; neurogenesis; radial glia; ErbB receptors; neuregulins]

Supplemental material is available at http://www.genesdev.org.

Received June 5, 2007; revised version accepted October 24, 2007.

Radial glial cells function as a source of new neurons and provide an instructive scaffold for neuronal migration during cerebral cortical development (Rakic 1972, 2003; Luskin 1998; Parnavelas 2000; Campbell and Gotz 2002; Gotz et al. 2002; Kriegstein and Gotz 2003; Tramontin et al. 2003). Subsequently, radial glia undergo terminal differentiation and give rise to astroglial and ependymal cells (Merkle et al. 2004; Spassky et al. 2005). Abnormalities in radial glial development, differentiation, and neuron-radial glial interactions lead to aberrant placement and connectivity of neurons in the human brain, an underlying cause of many developmental brain disorders such as schizophrenia, as well as gross brain malformations such as lissencephaly (for review, see Ross and Walsh 2001; Hatten 2002; Marin and Rubenstein 2003; Ayala et al. 2007). Since the generation and guidance of

${ }^{6}$ Corresponding author.

E-MAIL anton@med.unc.edu; FAX (919) 966-1844.

Article is online at http://www.genesdev.org/cgi/doi/10.1101/gad.1580407. neurons are two essential functions of radial glia, the ability to regain radial glial identity in the postnatal cerebral cortex could be of use in neural disease settings where there is a demand for neurogenesis and targeted guidance of neurons to repair and maintain functional neural circuitry.

Previously, Hunter and Hatten (1995) elegantly demonstrated that early postnatal astrocytes can dedifferentiate into radial glia in vitro in response to factors present in embryonic cortex. Recent studies have demonstrated that neuregulin1 (NRG1) signaling via ErbB2 plays a critical role in maintaining radial glial identity in the embryonic cerebral cortex (Patten et al. 2003, 2006; Schmid et al. 2003; Gierdalski et al. 2005). ErbB2 expression is down-regulated as radial glia transform into astrocytes. However, it is unclear if reactivating cellular and molecular constituents essential for early radial glial development is sufficient to regain radial glial identity in mature cerebral cortex, and whether these reactivated radial glial progenitor cells in the mature cortex can generate new neurons and support their migration. 
Here, we determined if re-expression of activated ErbB2 can induce mature astrocytes to revert to a radial glial progenitor phenotype in the adult cerebral cortex. Using a "tet-off" bitransgenic mouse system (hGFAP/ tTA; TetRE/ErbB2), ErbB2 was induced in vivo in mature astrocytes. We then determined if the induced astrocytes give rise to radial glial progenitors capable of generating new neurons and supporting glial-guided neuronal migration.

\section{Results}

In vivo reinduction of ErbB2 in mature astrocytes

To selectively reinduce ErbB2 in mature astroglial cells in vivo, we generated lines of bitransgenic mice (hGFAP/ tTA;TetRE/ErbB2) in which tetracycline-regulated expression of ErbB2 in astrocytes can be achieved. A valineto-glutamic acid point mutation within the transmembrane domain of ErbB2 results in the constitutive activation of ErbB2 independent of a ligand (Bargmann et al. 1986). A transgenic line in which this activated ErbB2 is under the control of a minimal CMV promoter and the tetracycline-responsive element (TetRE/ErbB2) was bred with a hGFAP promoter-tTA line (hGFAP/tTA), which expresses the tetracycline-responsive transcriptional activator (tTA) under the control of the human GFAP promoter (Xie et al. 1999; Ye et al. 2004). The resultant bitransgenic mouse model (hGFAP/tTA;TetRE/ErbB2) permits the activation of ErbB2 in astrocytes in the absence of tetracycline analog, doxycycline (Fig. 1A-C).

When crossed with the reporter line TetRE/LacZ, in which $\beta$-galactosidase is under the control of TetRE, the hGFAP/tTA transgene induced widespread, doxycyclineregulated expression of $L a c Z$, exclusively in $\mathrm{GFAP}^{+}$astrocytes (Fig. 1D-E; Lin et al. 2004). In general, due to the time it takes for the doxycycline to gradually clear from the mouse tissues, induced expression begins during the second week of doxycycline withdrawal (Baron and Bujard 2000; Lin et al. 2006, 2007).

To assess the efficacy of ErbB2 induction, 6-wk-old hGFAP/tTA; TetRE/ErbB2 mice were induced for $3 \mathrm{wk}$ and the cerebral cortices of the induced and uninduced control littermate mice were harvested to evaluate the level of ErbB2 induction. Cortices were processed either for mRNA purification and real-time PCR analysis with probes specific for ErbB2 transgene or for protein extraction and ErbB2 immunoprecipitation. Real-time PCR analysis of ErbB2 transgene induction in postnatal cortex revealed a significant increase of ErbB2 mRNA expression following the withdrawal of doxycycline (Fig. 1C). Furthermore, ErbB2 was immunoprecipitated from tissue lysates and probed with anti-ErbB2 and anti-phospho-tyrosine antibodies. Densitometric analysis of ErbB2 immunoprecipitates revealed that ErbB2 protein levels increased by approximately fourfold in induced cortices (Fig. 1C'). The induced ErbB2 proteins were tyrosine phosphorylated, suggesting that they are functionally active. These results indicate that there is a selective activation of ErbB2 in the mature astrocytes of induced, bitransgenic hGFAP/tTA;TetRE/ErbB2 mice.
Gross morphological examination of cerebral cortices isolated from ErbB2-induced mice showed prominent lateral ventricular enlargement following ErbB2 induction (Supplementary Fig. S1A,B). Furthermore, induced hGFAP/tTA; TetRE/ErbB2 mice were hyperactive compared with littermate controls, and display repetitive motor behavior such as spinning and flipping (Supplementary Fig. S1C).

\section{Can radial glial progenitor identity be regained in mature cerebral cortex?}

To test if the re-expression of ErbB2 in quiescent, mature astrocytes led to regaining of radial glial identity, we initially analyzed induced cortices with a battery of radial glial-specific indicators ( $\mathrm{RC} 1$, nestin, phosphorylated form of intermediate filament protein vimentin $[\mathrm{P}$ vimentin], brain lipid-binding protein [BLBP], Sox2, Pax6, Notch1, and Hes5) (Heins et al. 2002; Noctor et al. 2002; Ever and Gaiano 2005; Gotz and Barde 2005; Sottile et al. 2006). Nestin, P-vimentin, and BLBP are molecular markers of radial glia, whereas Pax6, Sox2, Hes5, and Notch 1 are transcription factors or signaling ligands essential for radial glial progenitor identity and potential. When ErbB2 was induced in mature astrocytes for 3 wk, there was strong re-expression of the radial glial marker, RC1, in a large number of cells, primarily around the ventricular zone, with long, radial processes oriented toward the pial surface (Fig. 1F-G"). These processes did not penetrate well into the cortical parenchyma as they do in the embryonic cortex. An increased expression of the active (i.e., phosphorylated) form of ErbB2 was evident in these cells (Fig. $\left.1 \mathrm{H}, \mathrm{H}^{\prime}\right)$. Although expression analysis with the TetRE/LacZ reporter mice suggests that hGFAP/tTA can induce TetRE driven gene expression in astrocytes throughout the cortex (Fig. 1D$\left.E^{\prime}\right)$, our observations suggest that only a subset of astrocytes found around the ventricles, but not those in the cortical parenchyma, can regain their radial glial molecular identity in the mature cerebral cortex following ErbB2 induction (Fig. 1F-G'). Analysis of radial glial marker expression was performed in the dorsal ventricular zone region (Fig. 2, schematic inset), which is normally devoid of radial glial marker expression. We further examined the effects of ErbB2 reinduction on the expression of other radial glia markers such as nestin, BLBP, and P-vimentin (Shibata et al. 1997; Noctor et al. 2002; Patten et al. 2003; Anthony et al. 2005). The radial morphology and density of cells expressing these markers was significantly increased in induced brains $(P<0.01$, Student's $t$-test) (Fig. 2A-C").

We then assessed changes in the expression of Notch1 ligand and transcription factors (Sox2, Pax6, and Hes5) with known roles in the generation and maintenance of radial glial cell identity (Ever and Gaiano 2005; Gotz and Barde 2005; Sottile et al. 2006). Although Sox2 and Pax6 were rarely expressed in control astroglial cells, following ErbB2 induction, both transcription factors were significantly up-regulated in the induced radial glia $(P<0.01$; Student's $t$-test) (Fig. 2D-E"). Furthermore, 
Figure 1. In vivo reinduction of ErbB2 in mature astrocytes of the adult cerebral cortex. (A) Developmental time line of radial glial and astrocytic development. Radial glia (green) are derived from neuroepithelial stem cells (blue). Around the time of birth, radial glia give rise to astrocytes (red). Down-regulation of ErbB2 expression parallels the transformation of radial glia into astrocytes. (B) To examine if reinduction of ErbB2 will enable regaining of radial glial identity in mature cerebral cortex, ErbB2 was induced in mature cortical astrocytes using a "TetOff" bitransgenic mouse model. hGFAP promoter-tTA transgene directs the expression of tTA in astrocytes. Binding of tTA to the TetRE, in the absence of Dox, leads to the induction of ErbB2 in astrocytes. $\left(C, C^{\prime}\right)$ Induction was achieved by removal of Dox at 6 wk postnatal, and brains were analyzed $3 \mathrm{wk}$ later. (C) Quantitative RT-PCR amplification analysis of ErbB2 transgene induction revealed a significant increase of ErbB2 expression. In the amplification curve, the induced samples contain more ErbB2 transcript; thus, the amount of SYBR Green fluorescence increases at an earlier cycle number. $\left(C^{\prime}\right)$ Immunoblot analysis of constitutively active ErbB2 expression in induced (-Dox) and uninduced (+Dox) adult mice indicates an up-regulation of ErbB2 expression at the protein level. $\left(D, D^{\prime}\right)$ hGFAP/tTA line crossed with an indicator line (TetRE/LacZ) demonstrates widespread induction of $L a c Z$ in astrocytes in the absence of Dox for $3 \mathrm{wk}$ in bitransgenic animals (hGFAP/tTA; TetRE/ $L a c Z)$. (E, E') Immunohistochemical staining of sections indicated that $L a c Z$ expression (green) was associated with astrocytes (red). $(F-H)$ The number of $\mathrm{RC1}^{+}$radial glial cells with elongated processes was significantly elevated in ErbB2-induced cortex, and these cells express activated (i.e., phosphorylated) ErbB2 (P-ErbB2). Data shown are mean cell density $\left(10^{4} / \mathrm{mm}^{3}\right) \pm$ SEM; asterisk indicates significance compared with controls at $P<0.01$ (Student's $t$-test).

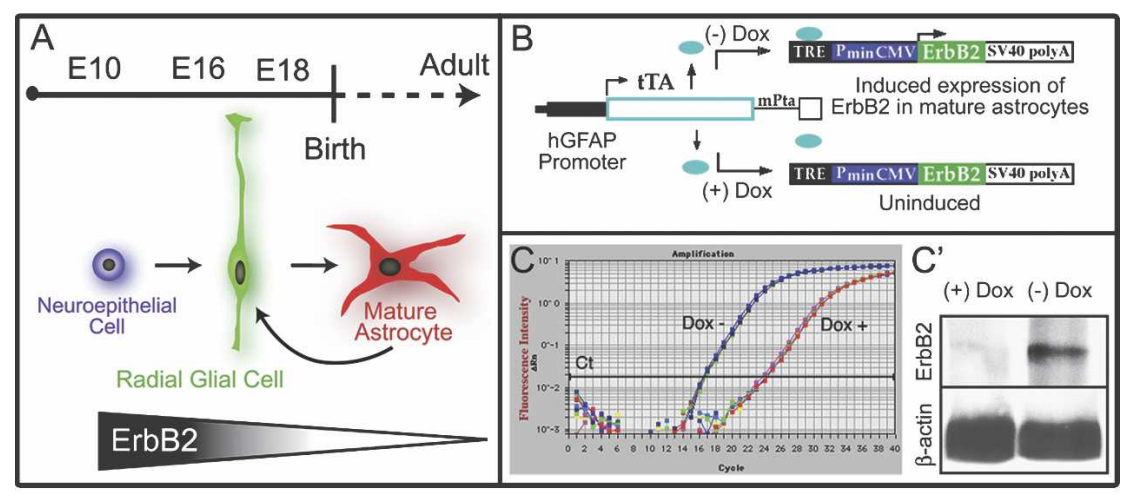

(+) Dox

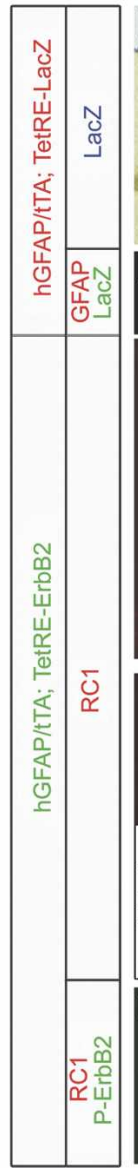

(-) Dox
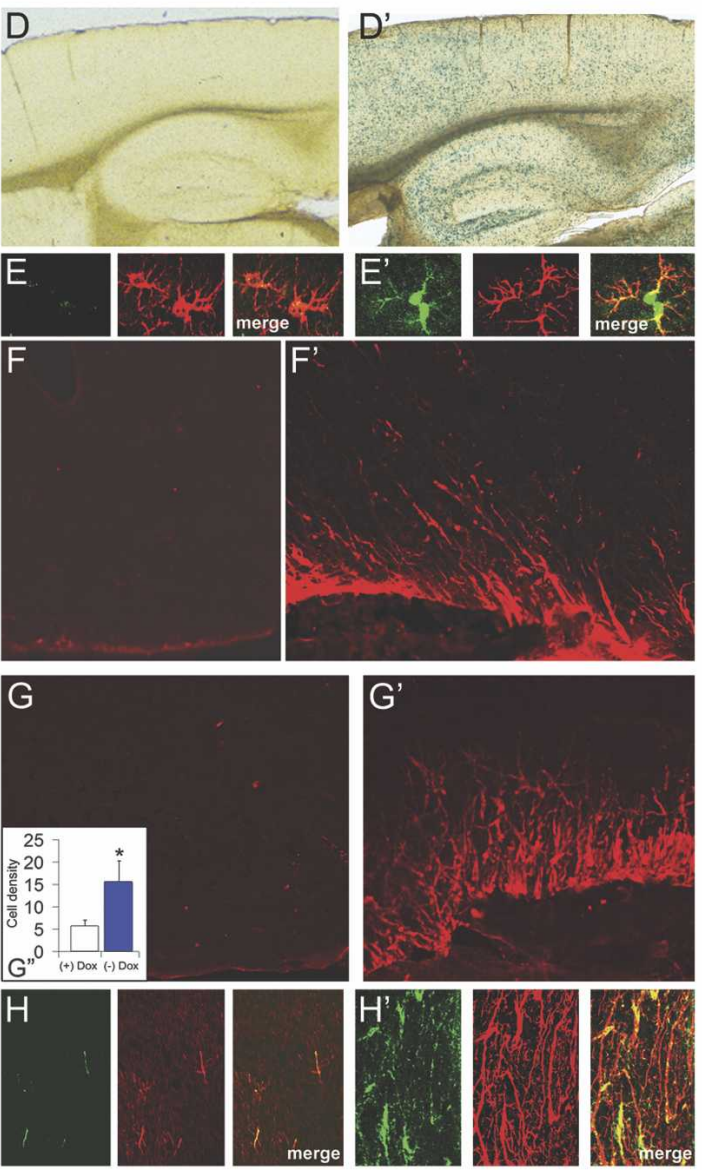

Notch1, which has been shown to be essential for the maintenance of radial glial identity, and its downstream activator, Hes5, were up-regulated following ErbB2 activation $\left(P<0.01\right.$, Student's $t$-test) (Fig. $\left.2 F-G^{\prime \prime}\right)$. Together, these analyses indicate that reinduction of ErbB2 in mature astrocytes leads to de novo induction of cells with molecular features of radial glia in the mature cortex, primarily around the ventricles, but not in the cortical parenchyma. These induced cells express elongated, polarized processes characteristic of radial glial cells. We therefore asked if these new radial glial cells in the adult cortex arose from mitotically active, newly generated radial glial progenitor cells, or were simply retransformed quiescent astrocytes, and if they had regained functional attributes (i.e., neural precursor, neuronal migration guide) of embryonic radial glia.

\section{Changes in proliferative capacity of ErbB2-induced astroglia}

To measure the effects of ErbB2 induction on proliferation, we administered the S-phase marker Bromodeoxyuridine (BrdU) daily for $1 \mathrm{wk}$ prior to sacrifice (Fig. 3A). There was a $7.9 \pm 1.4$-fold increase in the density of $\mathrm{BrdU}^{+} / \mathrm{RCl}^{+}$cells in the induced mice $(P<0.01$, Student's $t$-test) (Fig. 3B-B"). These BrdU ${ }^{+}$cells have elon- 


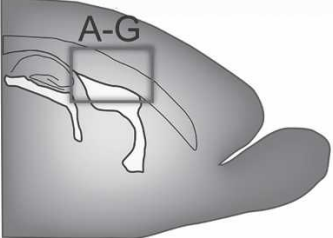

$(+)$ Dox
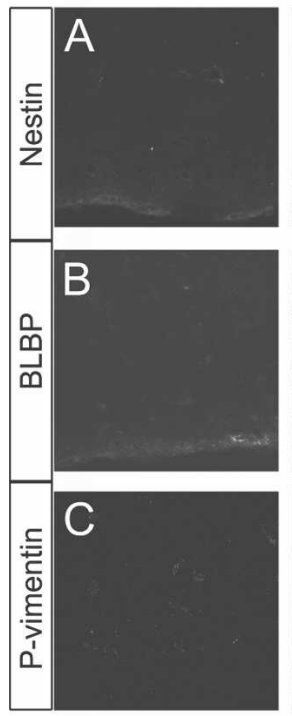

$(-)$ Dox
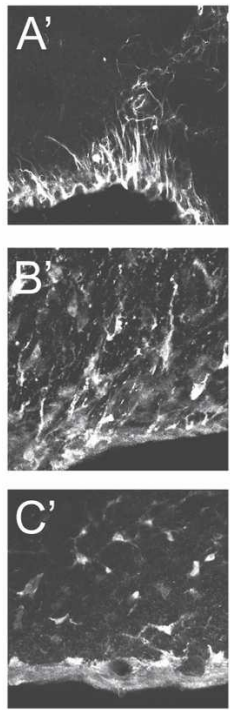

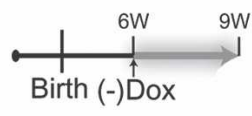

sw
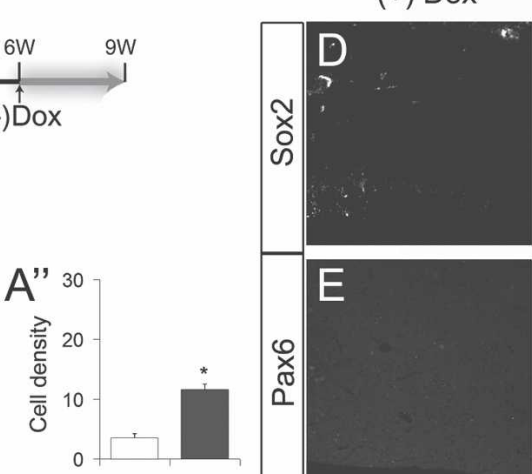

$(+)$ Dox (-) Dox

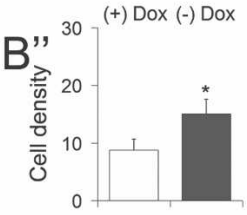

$(+) \operatorname{Dox}(-)$ Dox
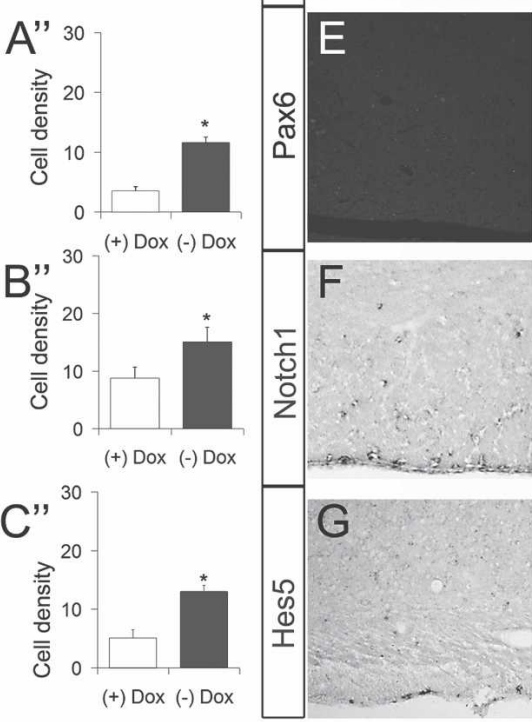
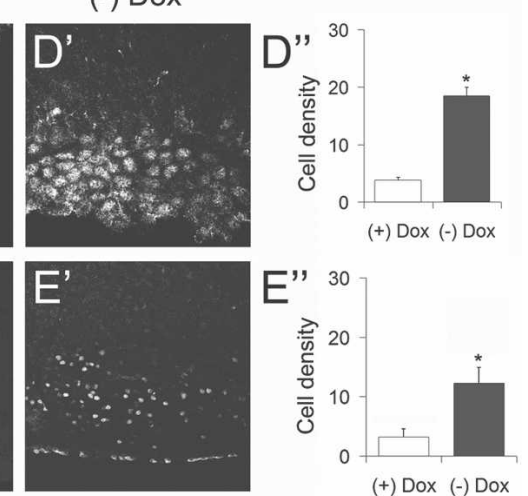

(+) Dox (-) Dox
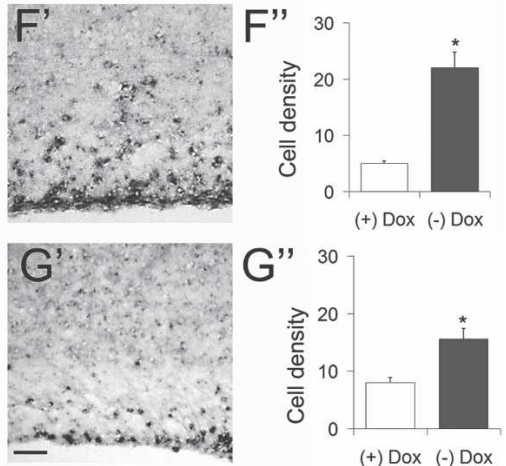

$(+)$ Dox (-) Dox

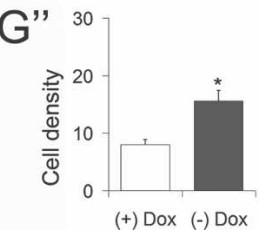

Figure 2. Induction of ErbB2 in mature astrocytes leads to re-expression of radial glial markers. When ErbB2 was induced in mature astrocytes (6-wk-old animals) for $3 \mathrm{wk}$, strong re-expression of radial glial markers was noticed in a large number of cells in the mature cerebral cortex. $(A-G)$ In uninduced controls, few, if any, radial glia marker-positive cells were noticed. Images were obtained from the area indicated by the boxed inset: $\left(\mathrm{A}-\mathrm{A}^{\prime \prime}\right)$ Nestin (Rat-401). (B- $\left.B^{\prime \prime}\right)$ BLBP. $\left(C-C^{\prime \prime}\right)$ Phosphorylated form of the P-vimentin. $\left(D-D^{\prime \prime}\right)$ Sox2. $\left(E-E^{\prime \prime}\right)$ Pax6. $\left(F-F^{\prime \prime}\right)$ Notch1. $\left(G-G^{\prime \prime}\right)$ Hes5. Notch1 and Hes5 were detected by in situ hybridization, and specific antibodies were used to immunolabel the other markers. Data shown are mean cell density $\left(10^{4} / \mathrm{mm}^{3}\right) \pm \mathrm{SEM}$; asterisk indicates significance compared with controls at $P<0.01$ (Student's $t$-test). Bar: $A-C, 45 \mu \mathrm{m} ; D, 30 \mu \mathrm{m} ; E, 60 \mu \mathrm{m} ; F, G, 110 \mu \mathrm{m}$.

gated processes (Fig. $3 \mathrm{~B}^{\prime}$, arrows) resembling radial glia. We then immunolabeled mitotic cells in control and induced brains with anti-phospho-histone $\mathrm{H} 3$ (PH3), and, as seen with BrdU labeling, ErbB2 induction resulted in more than a 13-fold increase in mitotically active, $\mathrm{PH}^{+}$, M-phase progenitor cells (uninduced, $0.13 \pm 0.08$; induced, $1.73 \pm 0.31$ cells $/ \mathrm{mm}^{3}, P<0.01$, Student's $t$-test). These results suggest that induction of ErbB2 in mature astrocytes leads to de novo generation and proliferation of radial glial cells. To further determine if cell cycle parameters of these mitotically active, ErbB2-induced cells were altered, we double-labeled $\mathrm{BrdU}^{+}$cells with Ki67, a marker for cells in S, G2, and $\mathrm{M}$ phases. $\mathrm{BrdU}^{+} /$ $\mathrm{Ki} 67^{+}$cells represent the fraction of cells that are still in cell cycle, whereas $\mathrm{BrdU}^{+} / \mathrm{Ki} 67^{-}$cells have exited the cell cycle (Fig. 3C, $\mathrm{C}^{\prime}$ ). The cell cycle exit index (ratio of $\mathrm{BrdU}^{+}, \mathrm{Ki} 67^{-} / \mathrm{BrdU}^{+}, \mathrm{Ki} 67^{+}$cells) indicates that ErbB2 induction did not cause changes in cell cycle exit of progenitors (Fig. 3C"). Taken together, these analyses clearly indicate that reinduction of ErbB2 in the adult astrocytes results in regaining of radial glial cell identity and enhanced proliferation of these dedifferentiated cells. Since a defining characteristic of radial glial cells is their ability to proliferate and generate new neurons, we exam- ined if the proliferating, ErbB2-induced radial glial progenitor cells can generate new neurons.

\section{ErbB2-induced radial glial progenitors give rise to neurons}

To determine the neurogenic potential of ErbB2-induced cells, single-cell suspensions of control and induced cells from the dorsal ventricular zone region were grown at low density in neurosphere medium for $10 \mathrm{~d}$ in vitro (10 DIV) (Fig. 4A). We tested their ability to form neurospheres, which are small spherical collections of dividing, nestin ${ }^{+}$neural precursor cells. ErbB2 induction promoted neurosphere formation, giving rise to nearlysevenfold higher number of neurospheres (Fig. 4B-B"). Furthermore, ErbB2 induction supported the continued passaging of neurospheres, whereas uninduced cells could not be passaged beyond their initial plating. ErbB2induced cells continued to generate higher number of neurospheres when compared with their uninduced counterparts (data not shown). These results support our in vivo observations that the ErbB2-induced cells can proliferate and self-renew, like radial glial progenitors.

To assess the potential of ErbB2-induced cells to gen- 


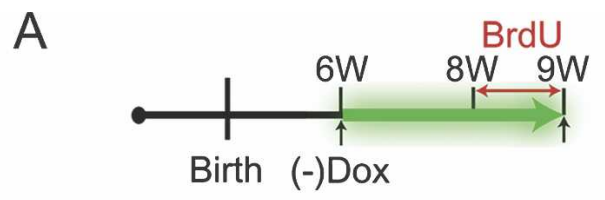

Figure 3. ErbB2-induced radial glial cells actively proliferate. $(A)$ BrdU was administered to induced and uninduced control mice 1 wk prior to sacrifice to label actively proliferating radial glial cells. $\left(B-B^{\prime \prime}\right)$ ErbB2 induction led to an increased number of $\mathrm{RC}^{+} /$ $\mathrm{BrdU}^{+}$radial glial cells. $\left(C-C^{\prime \prime}\right) \mathrm{BrdU}, \mathrm{Ki} 67$ colabeling indicates an enhanced number of actively cycling progenitors $\left(\mathrm{BrdU}^{+} / \mathrm{Ki} 67^{+}\right)$in the ErbB2-induced brains. Data shown are mean \pm SEM; asterisk indicates significance compared with controls at $P<0.01$ (Student's $t$-test).
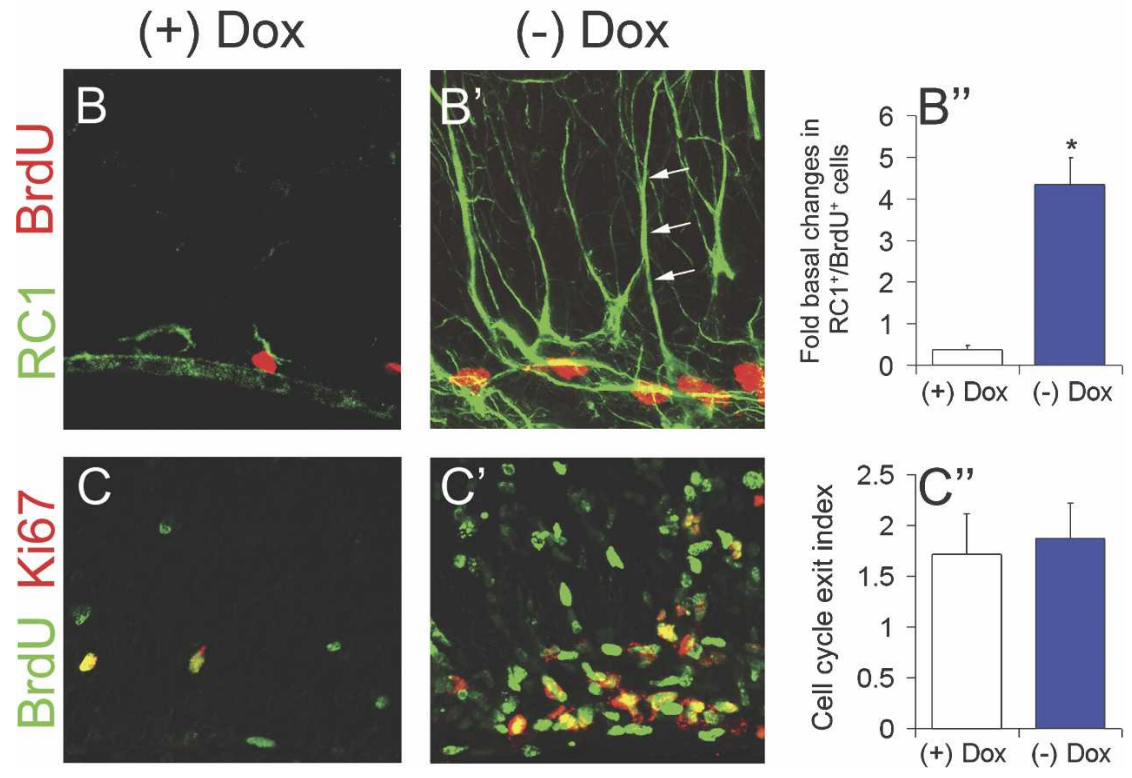

erate new neurons, neurospheres were allowed to differentiate on laminin coated substrate. Upon adhesion, both control and induced neurospheres gave rise to neurons $\left(\mathrm{TuJ}^{+}\right)$, astrocytes $\left(\mathrm{GFAP}^{+}\right)$, and oligodendrocytes $\left(\mathrm{NG}^{+}\right)$(Fig. 4D-G). However, the percentage of differentiated cells identified as neurons, using class III $\beta$-tubulin (TuJ1) as a marker, was 3.35-fold higher in the ErbB2induced group than in the control group (Fig. 4G). We then analyzed the neuronal subtypes generated from these neurospheres. Differentiated neurons generated from the uninduced progenitors were primarily GABAergic interneurons (Fig. 5A-A"). In contrast, neurospheres from ErbB2-induced precursors gave rise to GABAergic interneurons (Fig. 5A-A") as well as to neurons expressing markers such as Er81, Tbr1, and Brn1 (Fig. 5B-D") that define deeper and upper layer neurons in the cerebral cortex (Arber et al. 2000; Hevner et al. 2001; McEvilly et al. 2002).

To further analyze the ability of ErbB2-induced cells to give rise to neurons, control and induced cells from the dorsal ventricular zone region were dissociated and plated at clonal density. Isolated cells were marked, allowed to differentiate, and after $5 \mathrm{~d}$, the cellular composition of individual clones generated from control and induced cells were analyzed. TuJ-1 immunolabeling was used to detect the presence of neurons in these clones (Fig. 6A-C). Compared with controls, ErbB2-induced cells gave rise to 4.4-fold more neuron-containing clones. To examine the effect of ErbB2 induction on neuronal generation in vivo, we analyzed the cortices of control hGFAP/tTA;TetRE/LacZ mice or hGFAP/tTA;TetRE/
LacZ;TetRE/ErbB2 mice. In these mice, induced cells and their progeny express $L a c Z$ and we determined if there are any new neurons $\left(\mathrm{LacZ}^{+} / \mathrm{NeuN}^{+}\right)$in their cortices following ErbB2 induction. Clusters of $\mathrm{LacZ}^{+} /$ $\mathrm{NeuN}^{+}$neurons were evident in ErbB2-induced cortex. Compared with control hGFAP/tTA;TetRE/LacZ mice, in which only $L a c Z$ was induced, a significant increase in new neurons $(5.8 \pm 1.7$-fold) were detected in ErbB2induced mice (Fig. 6D-G). Together, these observations suggest that ErbB2-induced, radial glial progenitors in mature cortex can proliferate and give rise to different types of cortical neurons.

To assess the potential of neurons derived from ErbB2induced astrocytes to incorporate into the developing brain, we isolated dorsal ventricular zone region cells from induced (hGFAP/tTA;TetRE/LacZ;TetRE/ErbB2) and control (hGFAP/tTA; TetRE/LacZ) mice and injected them into the cerebral ventricles of embryonic day 16 (E16) mice in utero (Fig. 7A). LacZ expression was used to trace the transplanted cells and their progeny. After 48 $h$, injected brains were immunolabeled for $\beta$-gal to assess the level of incorporation of transplanted cells into the embryonic cerebral cortices. Very few of the adult-derived progenitor cells from control mice (hGFAP/ tTA; TetRE/LacZ) incorporated into the embryonic ventricular zone, and we could not detect any neuronal progeny of transplanted cells within the cortical plate (Fig. 7B). In contrast, a large number of adult-derived cells from ErbB2-induced mice incorporated well into the embryonic ventricular zone and gave rise to $\mathrm{TuJ} 1^{+}$neurons that had migrated into the cortical plate (Fig. 7C-E). 

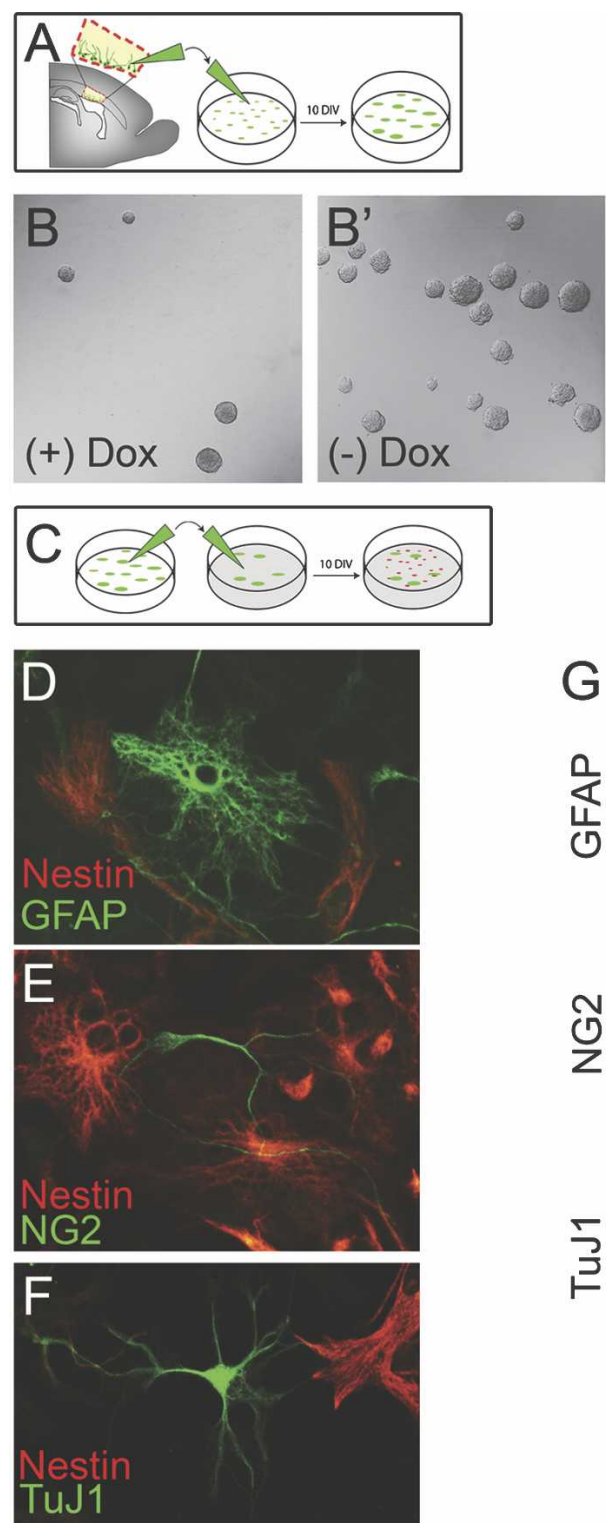

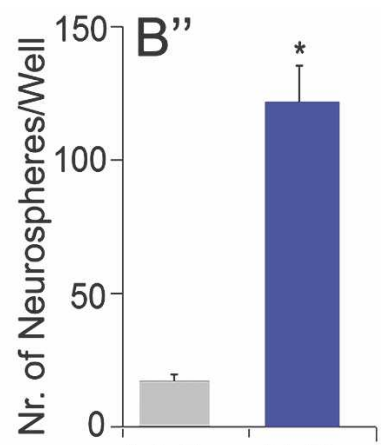

(+) Dox (-) Dox

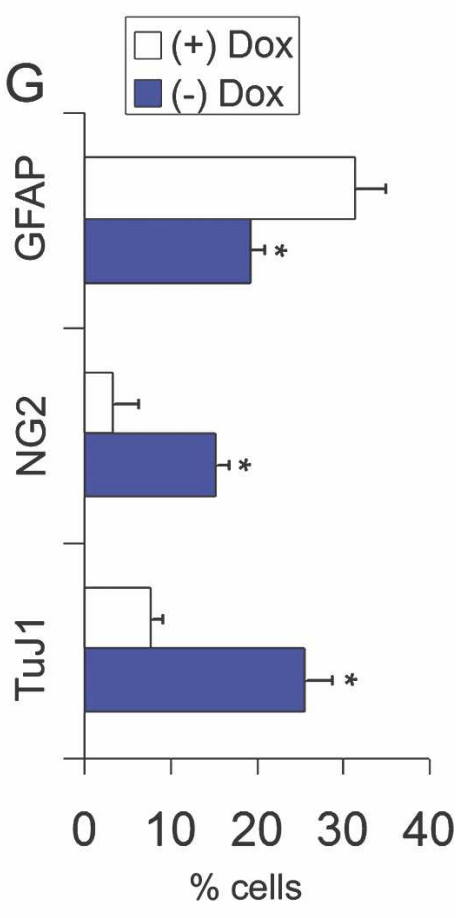

Figure 4. ErbB2-induced astrocytes give rise to neurons in vitro. $(A)$ Cells from the dorsal ventricular zone were microdissected from sagittal slices of induced and uninduced brains and were cultured in neurosphere media for $10 \mathrm{~d}$ in vitro. $\left(B-B^{\prime \prime}\right)$ ErbB2expressing cells gave rise to a significantly higher number of neurospheres. $(C)$ Induced and uninduced neurospheres were then plated on laminin-coated substrate and allowed to differentiate. $(D-F)$ Neurospheres from control and induced brains gave rise to astrocytes $\left(\mathrm{GFAP}^{+} ; D\right)$, oligodendrocytes $\left(\mathrm{NG}^{+} ; E\right)$, and neurons $\left(\mathrm{TuJ1} 1^{+} ; F\right) .(G)$ However, neurospheres from ErbB2-induced mice gave rise to a significantly higher percentage of neurons and oligodendrocytes than the uninduced controls. Data shown are mean \pm SEM; asterisk indicates significance compared with controls at $P<0.01$ (Student's $t$-test).

These results suggest that ErbB2-induced radial glial progenitors, when placed in an embryonic environment, are capable of incorporating into the ventricular zone of the developing cerebral cortex and giving rise to neurons.

\section{ErbB2-induced radial glial progenitors can support neuronal migration}

We next determined if astrocytes in hGFAP/tTA;TetRE/ ErbB2 mice, induced to assume a radial glial progenitor identity, could support glial guided neuronal migration as in the embryonic cortex. To assess this, EGFP ${ }^{+}$E16 cortical neurons from the $\beta$-Actin promoter-EGFP (ACTB-EGFP) mice were injected into the lateral ventricles of ErbB2-induced or control adult mice (Fig. 8A). Following a 1-wk survival period, the density and extent of $\mathrm{EGFP}^{+}$neuronal migration into the cortical parenchyma was assessed. The density and distance of EGFP ${ }^{+}$ neuronal migration from the lining of the ventricles was significantly higher $(P<0.01$, Student's $t$-test) (Fig. 8B$\mathrm{D})$ in the induced mice, suggesting that ErbB2-expressing radial glial progenitor cells in the mature cortex facilitate the migration of transplanted cortical neurons.

To examine this further, dissociated neurons from ACTB-EGFP cortices were seeded on sagittal cortical slices from induced and control adult brains. After $2 \mathrm{~h}$ in vitro, the extent of adhesion of $\mathrm{EGFP}^{+}$cells to cortical slices was analyzed. A 7.6 \pm 1.4 -fold higher number of embryonic neurons were found to be attached to the ErbB2-induced brain slices when compared with controls (Fig. $8 \mathrm{E}^{\prime}, \mathrm{F}^{\prime}, \mathrm{H}$ ). Many of these neurons were attached to the radial processes of ErbB2-induced, $\mathrm{RC}^{+}$radial glial cells (Fig. 8F'), whereas only occasional, rounded cells 
Figure 5. ErbB2-induced neurospheres give rise to multiple types of cortical neurons. Neurospheres derived from induced $(A-D)$ and control $\left(A^{\prime}-D^{\prime}\right)$ brains were allowed to differentiate and were colabeled with TuJ-1 and anti-GABA, Tbr1, Er81, or Brn1 antibodies. TuJ-1 labels all differentiated neurons $\left(\mathrm{TuJ} 1^{+}\right.$, green), whereas antiGABA $\left(A, A^{\prime}\right)$, Tbr1 $\left(B, B^{\prime}\right), \operatorname{Er} 81\left(C, C^{\prime}\right)$, and $\operatorname{Brn} 1\left(D, D^{\prime}\right)$ antibodies label interneurons, layer VI neurons, layer $\mathrm{V}$ neurons, and layer II-IV neurons, respectively. $\left(A^{\prime \prime}-D^{\prime \prime}\right)$ Control neurospheres gave rise to mainly GABAergic neurons, whereas neurospheres from ErbB2-induced brains gave rise to $\mathrm{GABA}^{+}, \mathrm{Tbr}^{+}, \mathrm{Er} 81^{+}$, and Brn1 ${ }^{+}$neurons. Data shown are mean \pm SEM; asterisk indicates significance compared with controls at $P<0.01$ (Student's $t$-test).

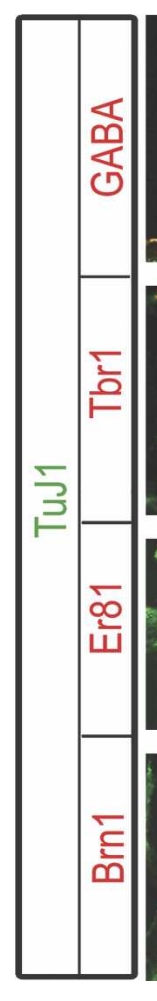

remained attached to the uninduced brains (Fig. 8F). We then live imaged the migratory potential of the seeded neurons using time-lapse confocal microscopy (Supplementary Movies 1, 2). In contrast to neurons seeded on control brains, $5.28 \pm 1.57$-fold more neurons were motile on ErbB2-induced brains. The average rate of migration of these neurons on ErbB2-induced slices was $38.9 \pm 4.7 \mu \mathrm{m} / \mathrm{h}$, whereas neurons on the uninduced brains were often nonmotile and migrated at an average rate of $3.6 \pm 0.4 \mu \mathrm{m} / \mathrm{h}$ (Fig. $\left.8 \mathrm{G}_{,} \mathrm{G}^{\prime}, \mathrm{I}\right)$. These results indicate that mature astrocytes in the adult brain induced to express ErbB2 and assume radial glial progenitor identity can support neuronal migration.

\section{Discussion}

Radial glial cells, through their function as neural precursors and guides of neuronal migration, play an essential role in the patterning of the mammalian cerebral cortex. Radial glia transform into astrocytes in the early postnatal brain. In vitro, this transformation is bidirectional and is thought to occur as a result of changes in the availability of inductive signals present in the embryonic brain (Hunter and Hatten 1995). Regaining of radial glial identity and function in the mature brain will be useful in the neural damage settings where there is a demand for neurogenesis and targeted guidance of neurons to repair and maintain functional neural circuitry. Here, we demonstrate that induction of the tyrosine kinase receptor, ErbB2, in mature astrocytes in vivo leads to the regaining of radial glial identity in distinct astrocytes. Consequently, these cells can generate new neurons and support guided neuronal migration.

\section{Regaining of radial glial identity in the mature brain}

ErbB2 was induced in mature astrocytes throughout the cerebral cortex; however, only a subset of astroglia present around the ventricles regained radial glial identity. This suggests that astrocytes in the mature cortex have distinctly different functional and differentiation potential. Those astrocytes in the cortical parenchyma and those adjacent to the vasculature are primarily involved in modulating neuronal activity and the blood-brain barrier, respectively (Haydon 2001). The critical significance of these astrocyte subsets in the integration of synaptic activity and the maintenance of cortical microenvironment may make their differentiation state more permanent and less malleable to reactivation of developmental cues. In contrast, the population of quiescent astrocytes around the ventricular surface differentiates into radial glia in response to re-expression of modulators of radial glial identity such as ErbB2.

The differences in the origin of these subsets of cortical astrocytes may underlie the disparity in their redevelopmental potential. During late stages of cortical development, radial glia can withdraw their processes and transform into multipolar astrocytes in the cortical parenchyma (Schmechel and Rakic 1979a,b). Final asymmetric division of radial glia in the ventricular zone can also give rise to a transforming daughter radial glia and to an intermediate precursor, which may eventually give rise to astrocytes (Doetsch et al. 1999; Noctor et al. 2004). The different developmental origin of astrocytes, in addition to their specific functions, may determine whether the postnatal induction of ErbB2 will enable astrocytes to regain radial glial identity in the adult cortex. 

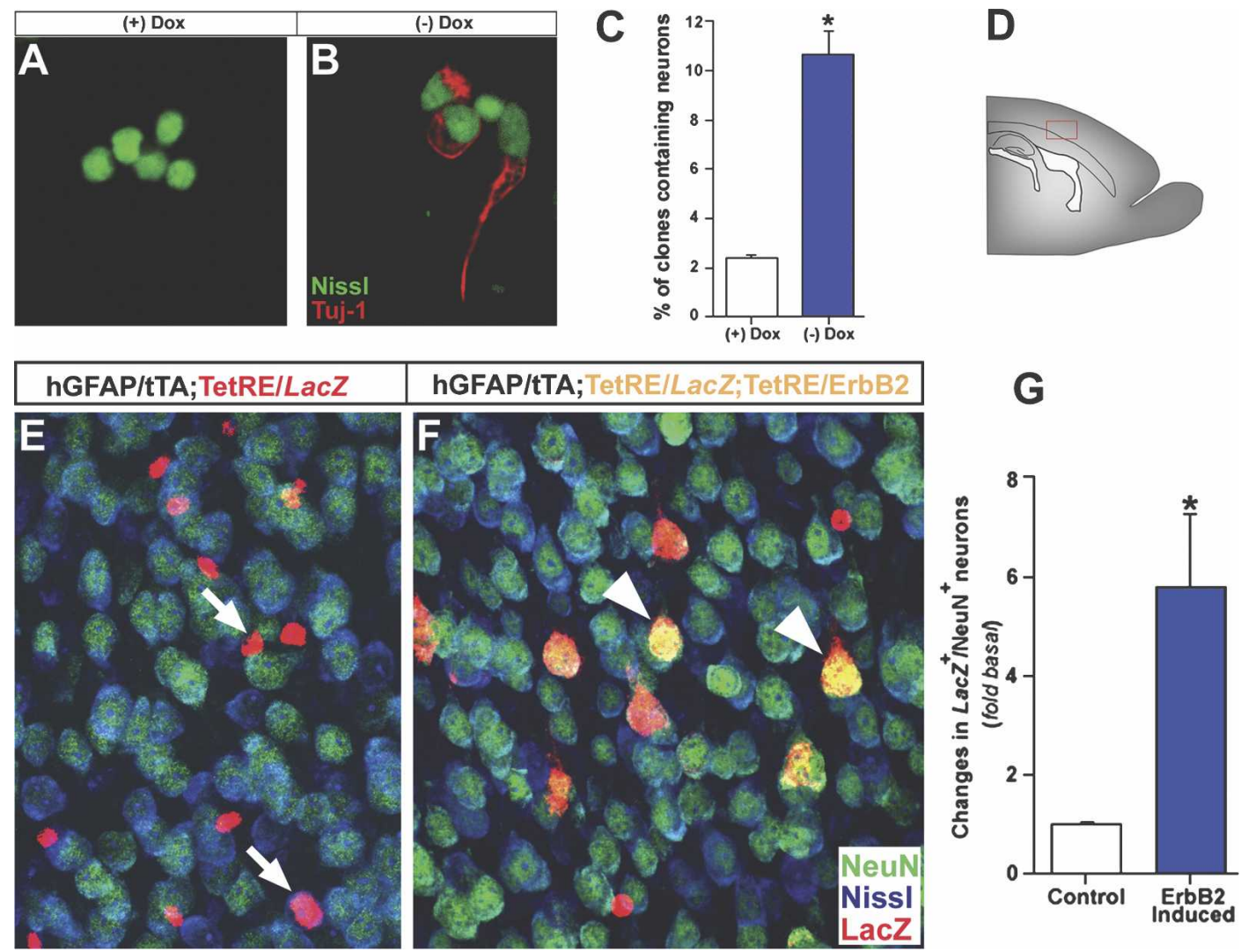

Figure 6. Generation of new neurons in ErbB2-induced brains. $(A-C)$ Isolated dorsal subventricular zone cells from induced and uninduced hGFAP/tTA;TetRE/ErbB2 mice were cultured at clonal density for $5 \mathrm{~d}$. Cells were then fixed, labeled with neuron-specific TuJ-1 antibodies, and nuclear-counterstained with green Nissl. The total number of clonal colonies and clones with $(B)$ or without $(A)$ neurons were quantified. $(C)$ ErbB2 induction leads to a significant increase in the number of TuJ-1-positive cell-containing clones. $(D-G)$ To analyze new neurons derived from induced astroglial cells in vivo, cortices from induced control hGFAP/tTA; TetRE/LacZ mice $(E)$ or hGFAP/tTA;TetRE/LacZ; TetRE/ErbB2 mice $(F)$ were coimmunolabeled with anti- $\beta$-galactosidase and neuron-specific NeuN antibodies. (E) LacZ expression delineates the progeny of induced cells. LacZ $Z^{+}$cells in control mice are not NeuN positive (arrows). (F) However, clusters of $\mathrm{LacZ}^{+} / \mathrm{NeuN}^{+}$neurons were evident following ErbB2 induction (arrowheads). (G) We noticed $5.8 \pm 1.7$-fold more LacZ/NeuN-positive neurons in ErbB2-induced cortices. $(E, F)$ Images were obtained from the area indicated by the boxed inset in $D$. Data shown are mean $\pm \mathrm{SEM}_{\text {; }}$ asterisk indicates significant when compared with controls at $P<0.01$.

ErbB2 induction in mature astrocytes may have transformed them into a radial glial progenitor cell type that differs from the neural stem cell type astrocytes normally residing in the anterior SVZ (aSVZ). The resident astroglial-like precursors in the aSVZ give rise to mostly GABAergic interneurons in vivo and in vitro (Kishi 1987; Luskin 1993; Lois and Alvarez-Buylla 1994; Doetsch and Alvarez-Buylla 1996; Gritti et al. 1996; De Marchis et al. 2001; Carlen et al. 2002; Petreanu and Alvarez-Buylla 2002; Carleton et al. 2003). However, ErbB2-induced astroglia can give rise to both GABAergic interneurons and projection neurons, similar to embryonic radial glia. Recent work by Shen et al. (2006) indicates that neural progenitors change their potency to generate different neuronal types during cortical development, and restrictions in this potential can be reversed within a temporal window of plasticity. For example, molecular regulators needed to generate the deeper layer cortical neurons are turned off in late gestation progenitors, thus generating neurons fated to become superficial layer neurons. This restricted potential can be partially reversed by the reexpression of key transcription factors, such as Foxg1 (Shen et al. 2006). During corticogenesis, a developmental decrease in ErbB2 expression parallels the gradual restrictions in neuropotency of cortical progenitors. Our results strongly suggest that inducing ErbB2 in adult astrocytes cells may have reactivated the neuropotency of induced radial glial cells, thus facilitating their ability to give rise to multiple classes of cortical neurons. Whether these neurons can incorporate into existing neural circuitry or survive long-term in the adult brain remains to be established.

\section{Reinduced radial glia can support neuronal migration}

ErbB2-induced radial glia in the adult cortex can support neuronal migration. Functional recovery in the injured nervous system requires not only the generation of new neurons, but also the appropriate guidance of neurons to where they are needed. The dorsal ventricular zone re- 

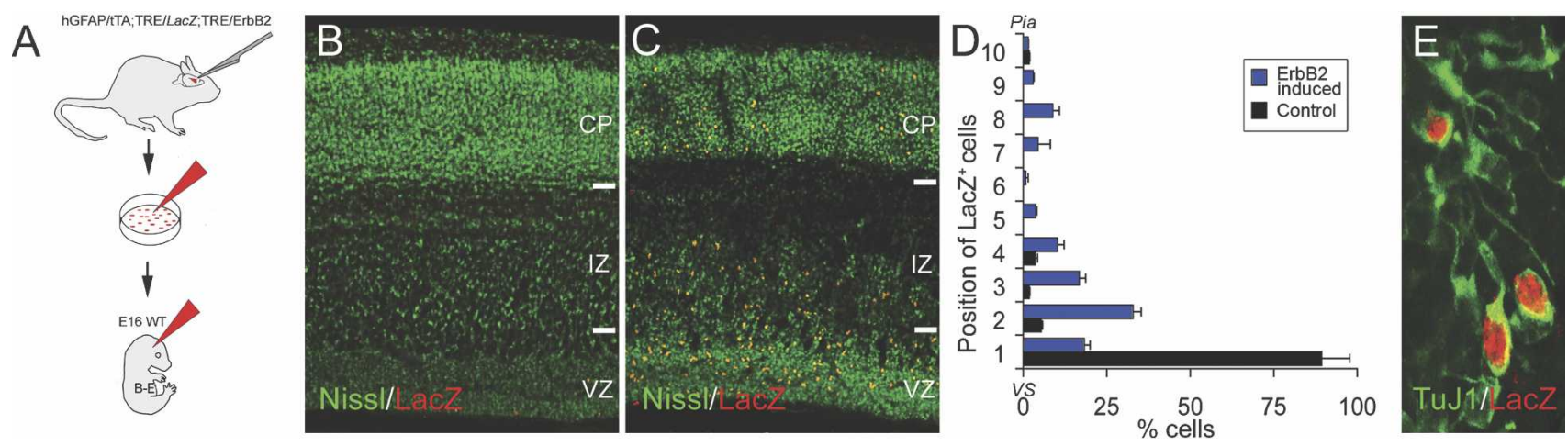

Figure 7. ErbB2-induced radial glial progenitors incorporate into the embryonic cerebral cortex. $(A)$ To assay the potential of ErbB2induced radial glial progenitors from the mature brain to incorporate into the embryonic cortex during development, dorsal ventricular zone cells from control and induced adult hGFAP/tTA;TetRE/LacZ;TetRE/ErbB2 mice were dissociated and injected into the cerebral ventricles of E16 wild-type mice in utero. $(B)$ After $48 \mathrm{~h}$, brains were harvested and immunolabeled for $\beta$-gal to assess the level of incorporation of transplanted cells into the embryonic cerebral cortices. Analysis of $\mathrm{LacZ}^{+}$cell position within the cerebral wall indicated that, in embryos injected with control cells (hGFAP/tTA;TRE/LacZ), very few of the injected LacZ $^{+}$cells incorporated into the developing cortex. $(C-E)$ In contrast, significantly higher numbers of ErbB2-induced cells incorporated into the embryonic ventricular zone, differentiated, and gave rise to $\mathrm{TuJ1} 1^{+}$neurons that migrated into the cortical plate. Data shown are mean $\pm \mathrm{SEM}$; the asterisk indicates significance compared with controls at $P<0.01$ (Student's $t$-test). (CP) Cortical plate; (IZ) intermediate zone; (VZ) ventricular zone; (VS) ventricular surface.

gion, where these new radial glia were induced, consists of a thin layer of ependymal cells with intermingled astrocytes, and an overlying white matter, rich in myelin and proteoglycans (Morest and Silver 2003; Silver and Miller 2004). Both myelin and proteoglycans can be inhibitory to cellular migration and process outgrowth (Filbin 1995, 2003; Niederost et al. 1999; Asher et al. 2002; He and Koprivica 2004; Schweigreiter et al. 2004; Yiu and He 2006). Thus, although ErbB2 induction can initiate a regaining of radial glial identity, the composition of the inhibitory cues within the cortical parenchyma may significantly impact the extension of radial glial processes and the ability of their neuronal progeny to migrate and incorporate into mature brain circuitry.

\section{Potential mechanisms involved in ErbB2 reinduced astrocytes}

Re-expression of ErbB2 led to up-regulation of the transcription factor Notch 1 and its effector gene, Hes5, in radial glial progenitors. Notch1 activity is critical for the maintenance of radial glial identity, and may promote the responsiveness of these cells to radial glial maintenance cues, such as neuregulins (Patten et al. 2003; Schmid et al. 2003; Patten et al. 2006). Additionally, Notch1 interacts with Suppressor of Hairless $[\mathrm{Su}(\mathrm{H})]$ and Deltex1 (DTX1) to regulate BLBP and ErbB2 expression, respectively (Patten et al. 2006). These two Notch1-dependent transcriptional mechanisms are hierarchically related and can coregulate radial glial formation (Eiraku et al. 2005; Patten et al. 2006). Attenuation of the Notch effector, C-promoter-binding factor $1[\mathrm{CBF} 1$; also known as $\mathrm{Su}(\mathrm{H})]$, signaling may facilitate the transition from radial glia/neural stem cells into intermediate neural progenitors in the cerebral cortex (Mizutani et al. 2007). When activated by neuregulins in the early embryonic cortical radial glia, a binding partner of ErbB2, ErbB4, undergoes presenilin-dependent cleavage of its intracellular signaling domain, which then complexes with the adaptor protein $\mathrm{TAB} 2$ and the corepressor $\mathrm{N}-\mathrm{CoR}$, translocates to the nucleus, binds to promoters of astrocytic genes, represses their expression, thus promoting radial glial phenotype (Sardi et al. 2006). Furthermore, activation of fibroblast growth factor receptor 2 (FGFR2) has also been shown to promote radial glial morphology in a Notch1 signaling-dependent manner (Yoon et al. 2004; Ever and Gaiano 2005). Numb/Numbl-mediated maintenance of radial glial adherens junctions is also required for radial glial morhpology (Rasin et al. 2007). Although how these interrelated signaling pathways are coordinated during radial glial morphogenesis and the precise nature of ErbB2-induced genetic reprogramming of mature astroglial cells (Mikkelsen et al. 2007; Okita et al. 2007; Wernig et al. 2007) remains to be fully elucidated, reinduction of ErbB2 in a subset of mature astrocytes appears to reactivate the expression of Pax6, Notch1, Hes5, and BLBP, thus reverting these cells to a radial glial phenotype. Analysis of Notch1-FGFR2 interactions during radial glial development suggests that the characteristic elongated radial glial morphology and its progenitor potential can be regulated via common signaling mechanisms, such as Notch1 cascade, or be separately modulated via mechanisms such as distinct FGF ligand signaling (Yoon et al. 2004). The ErbB2 signaling pathway appears to influence both the morphological and progenitor characteristics of radial glial phenotype.

ErbB2, although important for the differentiation of radial glia in the developing cortex, is also a known oncogenic tyrosine kinase receptor that is activated in many forms of cancer (Baselga 2006). Interestingly, cancerous stem cells arising from both adult and pediatric brain tumors have been shown to express genes prefer- 


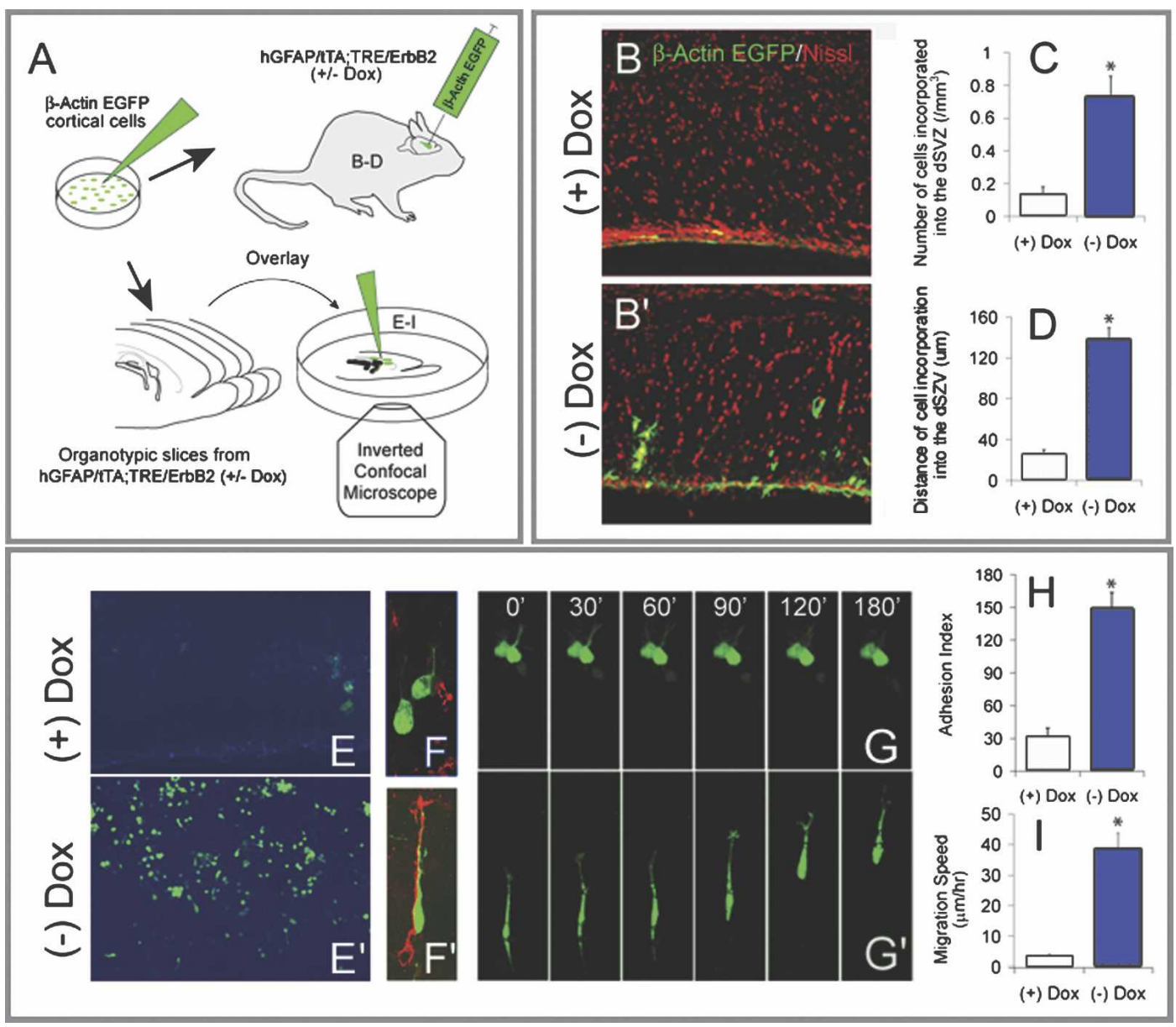

Figure 8. Newly induced radial glia can support neuronal migration. $(A)$ To assess the capacity of the ErbB2-induced radial glia to support neuronal migration in the mature cortex, EGFP-expressing embryonic cortical neurons were either injected into the lateral ventricles of control or induced mice $(B-D)$, or seeded on sagittal slices of induced and uninduced cortices $(E-G)$. $(B-D)$ Embryonic neurons were able to incorporate and migrate into the adult cortex when injected into the ErbB2-induced mice $\left(B^{\prime}\right)$ but not in the uninduced controls $(B)$. Both the density $(C)$ and the distance of migration $(D)$ of embryonic neurons were significantly higher in the ErbB2-induced mice, indicating the potential of induced radial glia to support neuronal migration. $\left(E, E^{\prime}, H\right) \mathrm{EGFP}^{+} \mathrm{embryonic}$ cortical neurons preferentially adhered to induced cortical slices $\left(E^{\prime}\right)$, while only a few cells attached to uninduced slices $(E, H) .\left(F, F^{\prime}\right)$ Embryonic neurons seeded on induced slices were attached to $\mathrm{RC}^{+}$radial processes $(F)$, whereas the occasional embryonic neurons found attached in uninduced slices were rounded and nonmotile $\left(F^{\prime}\right) .\left(G, G^{\prime}, H, I\right)$ Live imaging of these slice overlay assays indicate that embryonic neurons actively migrate on ErbB2-induced cortices, but not on control cortices. Minutes elapsed are indicated on each panel. Data shown are mean \pm SEM; asterisk indicates significance compared with controls at $P<0.01$ (Student's $t$-test). See also Supplementary Movies 1 and 2 .

entially found in neural stem cells (Tohyama et al. 1992; Ignatova et al. 2002; Hemmati et al. 2003; Galli et al. 2004; Singh et al. 2004). For example, platelet-derived growth factor receptor $\alpha$ (PDGFR $\alpha)$ activity, which in normal GFAP ${ }^{+}$neural stem cells of the SVZ modulates the balance between neurogenesis and oligodendrocyte generation (Jackson et al. 2006), is deregulated in oligodendrogilomas and astrocytomas (Guha et al. 1995; Varela et al. 2004). Transforming growth factor $\alpha$ (TGF $\alpha$ ) is a critical regulator of astrocyte formation, and TGF $\alpha$ signaling is frequently deregulated in gliomas (Sibilia et al. 1998; Junier 2000; Wechsler-Reya and Scott 2001). Prolonged exposure to TGF $\alpha$, which is overexpressed in earlier stages of glioma, can cause astrocytes in vitro to regress into neural progenitor-like cells (Sharif et al. 2006, 2007).
Furthermore, ErbB2 activation can up-regulate TGF $\alpha$ expression (Xie et al. 1999), thus further facilitating astrocyte transformation by recruiting additional relevant receptor tyrosine signaling cascades into this process.

In summary, these results indicate that the developmental differentiation and transformation of radial glia into astrocytes is bidirectional in vivo and raise the intriguing possibility that reinduced radial glia in the mature brain can be manipulated to generate and guide new neurons in the adult brain environment. Functional induction of developmental cues such as ErbB2 in mature astroglia may provide an avenue to facilitate neurogenesis and guidance of new neurons in the mature CNS where they might be needed to repair or maintain neural circuitry. 


\section{Materials and methods}

\section{Induction of ErbB2}

hGFAP/tTA and TetRE/ErbB2 transgenic lines were maintained on drinking water containing $2 \mathrm{mg} / \mathrm{mL}$ Doxycycline (Dox; Sigma) and 5\% sucrose (Xie et al. 1999; Lin et al. 2004; Ye et al. 2004). These lines were interbred to generate hGFAP/ tTA;TetRE/ErbB2 bitransgenic mice. ErbB2 induction was initiated in bitransgenic litters by the removal of Dox from water. Uninduced mice were maintained on Dox-water. hGFAP/ tTA;TetRE/LacZ;TetRE/ErbB2 and hGFAP/tTA;TetRE/LacZ mice were generated similarly (Kemper and Popko 2000).

\section{Behavior analysis}

Induced and uninduced hGFAP/tTA;TetRE/ErbB2 littermate mice (10 per group) were placed in a fresh clean cage with free access to food and water for $30 \mathrm{~min}$. After $3 \mathrm{~h}$ of acclamation, activity was measured as percentage of time spent actively moving inside the cage.

\section{Quantitative RT-PCR analysis and immunoblotting}

RNA was isolated using Trizol, reversibly transcribed using the SuperScript First Strand Synthesis System (Invitrogen), and quantitative RT-PCR was performed using SYBR Green PCR Master Mix on an ABI 7700 PCR Detection System (Applied Biosystems) with primers specific to GAPDH and ErbB2.

ErbB2 immunoprecipitates from brain extracts were separated by $4 \%-12 \%$ gradient SDS-PAGE and were immunoblotted with anti-ErbB2 or anti-phosphorylated-ErbB2 antibody (cErbB2; Neomarkers) as described previously (Schmid et al. 2003).

\section{Immunohistochemistry and cell cycle density}

Brain sections or dissociated cells from induced and control mice were immunolabeled as described previously (Ghashghaei et al. 2006) using the following antibodies: anti-RC1 and RC2 (Iowa Hybridoma); anti-phosphorylated ErbB2 (Neomarker); anti- $\beta$-gal (MP-Biomedical); anti-GFAP (Dako); anti-ErbB2 (Santa Cruz Biotechnology); TuJ1 and anti-Pax6 (Covance); antiGABA (Sigma); anti-GFP and anti-phosphorylated vimentin (Abcam); anti-GLAST, anti-Tbr1, anti-NG2, and anti-BLBP (Chemicon); anti- $\beta$-catenin (Sigma); anti-BrdU (Becton and Dickenson); anti-Ki67 (NovoCastra); anti-phosphorylated Histone3 (PH3; Upstate Biotechnology); anti-Caspase3 (Cell Signaling); anti-Sox2 (gift from Dr. L. Pevny, University of North Carolina); anti-Brn1 (gift of A. Ryan, McGill University); and anti-Er81 (gift of T. Jessell, Columbia University). Immunoreactivity was detected with appropriate Cy2- or Cy3-conjugated secondary antibodies (Jackson Immunoresearch).

Unbiased, stereological random sampling techniques and the StereoInvestigator software (MicroBrightField) were used to estimate the density of labeled cells (West and Gundersen 1990). Estimates of cell numbers and volumetric measurements of the dorsal ventricular zone region were obtained as described previously (Ghashghaei et al. 2006).

\section{Cell proliferation analysis}

Induced and uninduced mice were administered BrdU (100 mg/ $\mathrm{kg}$; Sigma) three times over a period of $1 \mathrm{wk}$ prior to sacrifice Cortices were then processed for cell cycle pattern analysis using anti-BrdU, anti-PH3, or anti-Ki67 immunolabeling as described previously (Ghashghaei et al. 2006).

\section{Neurosphere and transplantation assays}

Neurosphere formation and differentiation assays using cells from induced and uninduced hGFAP/tTA;TetRE/ErbB2 mice were performed as described previously (Anton et al. 2004; Ghashghaei et al. 2006).

Dissociated cells $(20,000$ cells per microliter) from E16 ACTBEGFP cortices in artificial cerebrospinal fluid were injected into the lateral ventricles of control and induced mice at a rate of 1 $\mu \mathrm{L} / \mathrm{min}$ using a stereotaxic apparatus (Stoelting) as described previously (Ghashghaei et al. 2006). After $1 \mathrm{wk}$ of survival, mice were perfused with $4 \%$ paraformaldehyde and their brains were removed, sagittally sectioned, and immunolabeled with antiEGFP antibodies to assess the extent of incorporation of transplanted cells into the mature cortex. In some experiments, dissociated cells from the dorsal ventricular zone region of induced hGFAP/tTA;TetRE/LacZ;TetRE/ErbB2 or hGFAP/tTA;TetRE/ $\mathrm{LacZ}$ mice were injected into the lateral ventricles of E16 wildtype mice. After $48 \mathrm{~h}$, injected brains were perfused with $4 \%$ paraformaldehyde, sectioned, and immunolabeled with anti- $\beta$ gal to assess the extent of incorporation of transplanted cells into the cortex. Some sections were colabeled with anti-GFAP, TuJ1, or anti-NG2 antibodies to determine the identity of transplanted cells.

\section{Clonal analysis of ErbB2-induced cells}

Dorsal subventricular zone cells from induced and uninduced hGFAP/tTA; TetRE/ErbB2 mice were dissociated and cultured at clonal density (500 cells per well) on glass coverslips in Neurobasal (NB)/N2/B27 medium. Location of single, isolated cells were noted $6 \mathrm{~h}$ after plating. After $5 \mathrm{~d}$ in vitro, cultures were fixed and colonies from single cells were labeled with neuronspecific Tuj-1 antibodies. The total number of clonal colonies present and colonies containing neurons were counted. Results were from five independent experiments. Statistical differences between experimental groups were tested by Student's $t$-test.

\section{Analysis of new neuronal generation in vivo}

To determine if ErbB2-induced cells can give rise to neurons in vivo, cortices from induced control hGFAP/tTA;TetRE/LacZ mice $(n=3)$ or hGFAP/tTA;TetRE/LacZ; TetRE/ErbB2 mice $(n=3)$ were coimmunolabeled with anti- $\beta$-galactosidase and neuron-specific NeuN antibodies. Mice were induced for 3.5 wk. LacZ expression marked the progeny of induced cells. Unbiased, stereological random sampling techniques and the StereoInvestigator software were used to estimate the density of $\mathrm{LacZ}^{+}$and $\mathrm{LacZ}^{+} / \mathrm{NeuN}^{+}$cells. Fold basal changes in $\mathrm{LacZ}^{+}$/ $\mathrm{NeuN}^{+}$cells were then determined.

\section{Analysis of induced radial glia's potential to support neuronal migration}

E16 cortical cells (100,000 cells per milliliter) were dissociated from ACTB-EGFP mice and were seeded on cortical slices from induced and uninduced mice as described before (Okabe et al. 1997; Anton et al. 2004). After $2 \mathrm{~h}$ of incubation at $37^{\circ} \mathrm{C} / 5 \%$ $\mathrm{CO}_{2}$, slices were rinsed in DMEM/N2/B27 and live-imaged using a Zeiss confocal microscope attached to a live cell incubation system for $3 \mathrm{~h}$ to visualize patterns of migration of EGFP ${ }^{+}$ cells on ErbB2-induced and control cortical substrates. Alternatively, some of the slices were fixed in $4 \%$ paraformaldehyde to quantify the levels of $\mathrm{EGFP}^{+}$cell adhesion to control and induced cortices. The extent of cell adhesion (adhesion index) was quantified by measuring the GFP fluorescence intensity within a $2500-\mu m^{2}$ area. 


\section{Acknowledgments}

We thank Christine Han, Hannah Watson, and Trevor Brothers for technical assistance, and Dr. Frank Longo for use of his StereoInvestigator software. This work was supported by NIH grant MH060929 to E.A., NIH NS34939 to B.P., NRSA fellowships to H.T.G. and J.M.W., and by the confocal imaging core of UNC Neuroscience Center's NINDS-funded Center grant.

\section{References}

Anthony, T.E., Mason, H.A., Gridley, T., Fishell, G., and Heintz, N. 2005. Brain lipid-binding protein is a direct target of Notch signaling in radial glial cells. Genes \& Dev. 19: 1028-1033.

Anton, E.S., Ghashghaei, H.T., Weber, J.L., McCann, C., Fischer, T.M., Cheung, I.D., Gassmann, M., Messing, A., Klein, R., Schwab, M.H., et al. 2004. Receptor tyrosine kinase ErbB4 modulates neuroblast migration and placement in the adult forebrain. Nat. Neurosci. 7: 1319-1328.

Arber, S., Ladle, D.R., Lin, J.H., Frank, E., and Jessell, T.M. 2000. ETS gene Er81 controls the formation of functional connections between group Ia sensory afferents and motor neurons. Cell 101: 485-498.

Asher, R.A., Morgenstern, D.A., Shearer, M.C., Adcock, K.H., Pesheva, P., and Fawcett, J.W. 2002. Versican is upregulated in CNS injury and is a product of oligodendrocyte lineage cells. J. Neurosci. 22: 2225-2236.

Ayala, R., Shu, T., and Tsai, L.H. 2007. Trekking across the brain: The journey of neuronal migration. Cell 128: 29-43.

Bargmann, C.I., Hung, M.C., and Welnberg, A.A. 1986. Multiple independent activations of the neu oncogene by a point mutation altering the transmembrane domain of p185. Cell 45: 649-657.

Baron, U. and Bujard, H. 2000. Tet repressor-based system for regulated gene expression in eukaryotic cells: Principles and advances. Methods Enzymol. 327: 401-421.

Baselga, J. 2006. Targeting tyrosine kinases in cancer: The second wave. Science 312: 1175-1178.

Campbell, K. and Gotz, M. 2002. Radial glia: Multi-purpose cells for vertebrate brain development. Trends Neurosci. 25: 235-238.

Carlen, M., Cassidy, R.M., Brismar, H., Smith, G.A., Enquist, L.W., and Frisen, J. 2002. Functional integration of adultborn neurons. Curr. Biol. 12: 606-608.

Carleton, A., Petreanu, L.T., Lansford, R., Alvarez-Buylla, A., and Lledo, P.M. 2003. Becoming a new neuron in the adult olfactory bulb. Nat. Neurosci. 6: 507-518.

De Marchis, S., Fasolo, A., Shipley, M., and Puche, A. 2001. Unique neuronal tracers show migration and differentiation of SVZ progenitors in organotypic slices. J. Neurobiol. 49: 326-338.

Doetsch, F. and Alvarez-Buylla, A. 1996. Network of tangential pathways for neuronal migration in adult mammalian brain. Proc. Natl. Acad. Sci. 93: 14895-14900.

Doetsch, F., Caille, I., Lim, D.A., Garcia-Verdugo, J.M., and Alvarez-Buylla, A. 1999. Subventricular zone astrocytes are neural stem cells in the adult mammalian brain. Cell 97: 703-716.

Eiraku, M., Tohgo, A., Ono, K., Kaneko, M., Fujishima, K., Hirano, T., and Kengaku, M. 2005. DNER acts as a neuronspecific Notch ligand during Bergmann glial development. Nat. Neurosci. 8: 873-880.

Ever, L. and Gaiano, N. 2005. Radial 'glial' progenitors: Neurogenesis and signaling. Curr. Opin. Neurobiol. 15: 29-33.

Filbin, M.T. 1995. Myelin-associated glycoprotein: A role in myelination and in the inhibition of axonal regeneration? Curr. Opin. Neurobiol. 5: 588-595.

Filbin, M.T. 2003. Myelin-associated inhibitors of axonal regeneration in the adult mammalian CNS. Nat. Rev. Neurosci. 4: 703-713.

Galli, R., Binda, E., Orfanelli, U., Cipelletti, B., Gritti, A., De Vitis, S., Fiocco, R., Foroni, C., Dimeco, F., and Vescovi, A. 2004. Isolation and characterization of tumorigenic, stemlike neural precursors from human glioblastoma. Cancer Res. 64: 7011-7021.

Ghashghaei, H.T., Weber, J., Pevny, L., Schmid, R., Schwab, M.H., Lloyd, K.C., Eisenstat, D.D., Lai, C., and Anton, E.S. 2006. The role of neuregulin-ErbB4 interactions on the proliferation and organization of cells in the subventricular zone. Proc. Natl. Acad. Sci. 103: 1930-1935.

Gierdalski, M., Sardi, S.P., Corfas, G., and Juliano, S.L. 2005. Endogenous neuregulin restores radial glia in a (ferret) model of cortical dysplasia. J. Neurosci. 25: 8498-8504.

Gotz, M. and Barde, Y.A. 2005. Radial glial cells defined and major intermediates between embryonic stem cells and CNS neurons. Neuron 46: 369-372.

Gotz, M., Hartfuss, E., and Malatesta, P. 2002. Radial glial cells as neuronal precursors: A new perspective on the correlation of morphology and lineage restriction in the developing cerebral cortex of mice. Brain Res. Bull. 57: 777-788.

Gritti, A., Parati, E.A., Cova, L., Frolichsthal, P., Galli, R., Wanke, E., Faravelli, L., Morassutti, D.J., Roisen, F., Nickel, D.D., et al. 1996. Multipotential stem cells from the adult mouse brain proliferate and self-renew in response to basic fibroblast growth factor. J. Neurosci. 16: 1091-1100.

Guha, A., Dashner, K., Black, P.M., Wagner, J.A., and Stiles, C.D. 1995. Expression of PDGF and PDGF receptors in human astrocytoma operation specimens supports the existence of an autocrine loop. Int. J. Cancer 60: 168-173.

Hatten, M.E. 2002. New directions in neuronal migration. Science 297: 1660-1663.

Haydon, P.G. 2001. GLIA: Listening and talking to the synapse. Nat. Rev. Neurosci. 2: 185-193.

He, Z. and Koprivica, V. 2004. The Nogo signaling pathway for regeneration block. Annu. Rev. Neurosci. 27: 341-368.

Heins, N., Malatesta, P., Cecconi, F., Nakafuku, M., Tucker, K.L., Hack, M.A., Chapouton, P., Barde, Y.A., and Gotz, M. 2002. Glial cells generate neurons: The role of the transcription factor Pax6. Nat. Neurosci. 5: 308-315.

Hemmati, H.D., Nakano, I., Lazareff, J.A., Masterman-Smith, M., Geschwind, D.H., Bronner-Fraser, M., and Kornblum, H.I. 2003. Cancerous stem cells can arise from pediatric brain tumors. Proc. Natl. Acad. Sci. 100: 15178-15183.

Hevner, R.F., Shi, L., Justice, N., Hsueh, Y., Sheng, M., Smiga, S., Bulfone, A., Goffinet, A.M., Campagnoni, A.T., and Rubenstein, J.L. 2001. Tbrl regulates differentiation of the preplate and layer 6. Neuron 29: 353-366.

Hunter, K.E. and Hatten, M.E. 1995. Radial glial cell transformation to astrocytes is bidirectional: Regulation by a diffusible factor in embryonic forebrain. Proc. Natl. Acad. Sci. 92: 2061-2065.

Ignatova, T.N., Kukekov, V.G., Laywell, E.D., Suslov, O.N., Vrionis, F.D., and Steindler, D.A. 2002. Human cortical glial tumors contain neural stem-like cells expressing astroglial and neuronal markers in vitro. Glia 39: 193-206.

Jackson, E.L., Garcia-Verdugo, J.M., Gil-Perotin, S., Roy, M., Quinones-Hinojosa, A., VandenBerg, S., and Alvarez-Buylla, A. 2006. PDGFR $\alpha$-positive B cells are neural stem cells in the adult SVZ that form glioma-like growths in response to increased PDGF signaling. Neuron 51: 187-199.

Junier, M.P. 2000. What role(s) for TGF $\alpha$ in the central nervous 
system? Prog. Neurobiol. 62: 443-473.

Kemper, A. and Popko, B. 2000. Tetracycline inducible system allows for controlled CNS IFN- $\gamma$ expression. J. Neurochem. 74: S67D.

Kishi, K. 1987. Golgi studies on the development of granule cells of the rat olfactory bulb with reference to migration in the subependymal layer. I. Comp. Neurol. 258: 112-124.

Kriegstein, A.R. and Gotz, M. 2003. Radial glia diversity: A matter of cell fate. Glia 43: 37-43.

Lin, W., Kemper, A., McCarthy, K.D., Pytel, P., Wang, J.P., Campbell, I.L., Utset, M.F., and Popko, B. 2004. Interferon- $\gamma$ induced medulloblastoma in the developing cerebellum. $J$. Neurosci. 24: 10074-10083.

Lin, W., Kemper, A., Dupree, J.L., Harding, H.P., Ron, D., and Popko, B. 2006. Interferon- $\gamma$ inhibits central nervous system remyelination through a process modulated by endoplasmic reticulum stress. Brain 129: 1306-1318.

Lin, W., Bailey, S.L., Ho, H., Harding, H.P., Ron, D., Miller, S.D., and Popko, B. 2007. The integrated stress response prevents demyelination by protecting oligodendrocytes against immune-mediated damage. J. Clin. Invest. 117: 448-456.

Lois, C. and Alvarez-Buylla, A. 1994. Long-distance neuronal migration in the adult mammalian brain. Science 264: 11451148.

Luskin, M.B. 1993. Restricted proliferation and migration of postnatally generated neurons derived from the forebrain subventricular zone. Neuron 11: 173-189.

Luskin, M.B. 1998. Neuroblasts of the postnatal mammalian forebrain: Their phenotype and fate. J. Neurobiol. 36: 221233.

Marin, O. and Rubenstein, J.L. 2003. Cell migration in the forebrain. Annu. Rev. Neurosci. 26: 441-483.

McEvilly, R.J., de Diaz, M.O., Schonemann, M.D., Hooshmand, F., and Rosenfeld, M.G. 2002. Transcriptional regulation of cortical neuron migration by POU domain factors. Science 295: $1528-1532$.

Merkle, F.T., Tramontin, A.D., Garcia-Verdugo, J.M., and Alvarez-Buylla, A. 2004. Radial glia give rise to adult neural stem cells in the subventricular zone. Proc. Natl. Acad. Sci. 101: 17528-17532.

Mikkelsen, T.S., Ku, M., Jaffe, D.B., Issac, B., Lieberman, E., Giannoukos, G., Alvarez, P., Brockman, W., Kim, T.K., Koche, R.P., et al. 2007. Genome-wide maps of chromatin state in pluripotent and lineage-committed cells. Nature 448: $553-560$

Mizutani, K., Yoon, K., Dang, L., Tokunaga, A., and Gaiano, N. 2007. Differential Notch signalling distinguishes neural stem cells from intermediate progenitors. Nature 449: 351355

Morest, D.K. and Silver, J. 2003. Precursors of neurons, neuroglia, and ependymal cells in the CNS: What are they? Where are they from? How do they get where they are going? Glia 43: 6-18.

Niederost, B.P., Zimmermann, D.R., Schwab, M.E., and Bandtlow, C.E. 1999. Bovine CNS myelin contains neurite growthinhibitory activity associated with chondroitin sulfate proteoglycans. J. Neurosci. 19: 8979-8989.

Noctor, S.C., Flint, A.C., Weissman, T.A., Wong, W.S., Clinton, B.K., and Kriegstein, A.R. 2002. Dividing precursor cells of the embryonic cortical ventricular zone have morphological and molecular characteristics of radial glia. J. Neurosci. 22: 3161-3173.

Noctor, S.C., Martinez-Cerdeno, V., Ivic, L., and Kriegstein, A.R. 2004. Cortical neurons arise in symmetric and asymmetric division zones and migrate through specific phases. Nat. Neurosci. 7: 136-144.
Okabe, M., Ikawa, M., Kominami, K., Nakanishi, T., and Nishimune, Y. 1997. 'Green mice' as a source of ubiquitous green cells. FEBS Lett. 407: 313-319.

Okita, K., Ichisaka, T., and Yamanaka, S. 2007. Generation of germline-competent induced pluripotent stem cells. Nature 448: 313-317.

Parnavelas, J.G. 2000. The origin and migration of cortical neurones: New vistas. Trends Neurosci. 23: 126-131.

Patten, B.A., Peyrin, J.M., Weinmaster, G., and Corfas, G. 2003. Sequential signaling through Notch 1 and erbB receptors mediates radial glia differentiation. J. Neurosci. 23: 6132-6140.

Patten, B.A., Sardi, S.P., Koirala, S., Nakafuku, M., and Corfas, G. 2006. Notch1 signaling regulates radial glia differentiation through multiple transcriptional mechanisms. I. Neurosci. 26: 3102-3108.

Petreanu, L. and Alvarez-Buylla, A. 2002. Maturation and death of adult-born olfactory bulb granule neurons: Role of olfaction. J. Neurosci. 22: 6106-6113.

Rakic, P. 1972. Mode of cell migration to the superficial layers of fetal monkey neocortex. J. Comp. Neurol. 145: 61-83.

Rakic, P. 2003. Developmental and evolutionary adaptations of cortical radial glia. Cereb. Cortex 13: 541-549.

Rasin, M.R., Gazula, V.R., Breunig, J.J., Kwan, K.Y., Johnson, M.B., Liu-Chen, S., Li, H.S., Jan, L.Y., Jan, Y.N., Rakic, P., et al. 2007. Numb and Numbl are required for maintenance of cadherin-based adhesion and polarity of neural progenitors. Nat. Neurosci. 10: 819-827.

Ross, M.E. and Walsh, C.A. 2001. Human brain malformations and their lessons for neuronal migration. Annu. Rev. Neurosci. 24: 1041-1070.

Sardi, S.P., Murtie, J., Koirala, S., Patten, B.A., and Corfas, G. 2006. Presenilin-dependent ErbB4 nuclear signaling regulates the timing of astrogenesis in the developing brain. Cell 127: 185-197.

Schmechel, D.E. and Rakic, P. 1979a. Arrested proliferation of radial glial cells during midgestation in rhesus monkey. $\mathrm{Na}$ ture 277: 303-305.

Schmechel, D.E. and Rakic, P. 1979b. A Golgi study of radial glial cells in developing monkey telencephalon: Morphogenesis and transformation into astrocytes. Anat. Embryol. (Ber1.) 156: 115-152.

Schmid, R.S., McGrath, B., Berechid, B.E., Boyles, B., Marchionni, M., Sestan, N., and Anton, E.S. 2003. Neuregulin 1-erbB2 signaling is required for the establishment of radial glia and their transformation into astrocytes in cerebral cortex. Proc. Natl. Acad. Sci. 100: 4251-4256.

Schweigreiter, R., Walmsley, A.R., Niederost, B., Zimmermann, D.R., Oertle, T., Casademunt, E., Frentzel, S., Dechant, G., Mir, A., and Bandtlow, C.E. 2004. Versican V2 and the central inhibitory domain of Nogo-A inhibit neurite growth via p75NTR/NgR-independent pathways that converge at RhoA. Mol. Cell. Neurosci. 27: 163-174.

Sharif, A., Prevot, V., Renault-Mihara, F., Allet, C., Studler, J.M., Canton, B., Chneiweiss, H., and Junier, M.P. 2006. Transforming growth factor $\alpha$ acts as a gliatrophin for mouse and human astrocytes. Oncogene 25: 4076-4085.

Sharif, A., Legendre, P., Prevot, V., Allet, C., Romao, L., Studler, J.M., Chneiweiss, H., and Junier, M.P. 2007. Transforming growth factor $\alpha$ promotes sequential conversion of mature astrocytes into neural progenitors and stem cells. Oncogene 26: 2695-2706.

Shen, Q., Wang, Y., Dimos, J.T., Fasano, C.A., Phoenix, T.N., Lemischka, I.R., Ivanova, N.B., Stifani, S., Morrisey, E.E., and Temple, S. 2006. The timing of cortical neurogenesis is encoded within lineages of individual progenitor cells. Nat. Neurosci. 9: 743-751. 
Shibata, T., Yamada, K., Watanabe, M., Ikenaka, K., Wada, K., Tanaka, K., and Inoue, Y. 1997. Glutamate transporter GLAST is expressed in the radial glia-astrocyte lineage of developing mouse spinal cord. J. Neurosci. 17: 9212-9219.

Sibilia, M., Steinbach, J.P., Stingl, L., Aguzzi, A., and Wagner, E.F. 1998. A strain-independent postnatal neurodegeneration in mice lacking the EGF receptor. EMBO J. 17: 719-731.

Silver, J. and Miller, J.H. 2004. Regeneration beyond the glial scar. Nat. Rev. Neurosci. 5: 146-156.

Singh, S.K., Hawkins, C., Clarke, I.D., Squire, J.A., Bayani, J., Hide, T., Henkelman, R.M., Cusimano, M.D., and Dirks, P.B. 2004. Identification of human brain tumour initiating cells. Nature 432: 396-401.

Sottile, V., Li, M., and Scotting, P.J. 2006. Stem cell marker expression in the Bergmann glia population of the adult mouse brain. Brain Res. 1099: 8-17.

Spassky, N., Merkle, F.T., Flames, N., Tramontin, A.D., GarciaVerdugo, J.M., and Alvarez-Buylla, A. 2005. Adult ependymal cells are postmitotic and are derived from radial glial cells during embryogenesis. J. Neurosci. 25: 10-18.

Tohyama, T., Lee, V.M., Rorke, L.B., Marvin, M., McKay, R.D., and Trojanowski, J.Q. 1992. Nestin expression in embryonic human neuroepithelium and in human neuroepithelial tumor cells. Lab. Invest. 66: 303-313.

Tramontin, A.D., Garcia-Verdugo, J.M., Lim, D.A., and AlvarezBuylla, A. 2003. Postnatal development of radial glia and the ventricular zone (VZ): A continuum of the neural stem cell compartment. Cereb. Cortex 13: 580-587.

Varela, M., Ranuncolo, S.M., Morand, A., Lastiri, J., De Kier Joffe, E.B., Puricelli, L.I., and Pallotta, M.G. 2004. EGF-R and PDGF-R, but not bcl-2, overexpression predict overall survival in patients with low-grade astrocytomas. J. Surg. Oncol. 86: 34-40.

Wernig, M., Meissner, A., Foreman, R., Brambrink, T., Ku, M., Hochedlinger, K., Bernstein, B.E., and Jaenisch, R. 2007. In vitro reprogramming of fibroblasts into a pluripotent ES-celllike state. Nature 448: 318-324.

Wechsler-Reya, R. and Scott, M.P. 2001. The developmental biology of brain tumors. Annu. Rev. Neurosci. 24: 385-428.

West, M.J. and Gundersen, H.J. 1990. Unbiased stereological estimation of the number of neurons in the human hippocampus. J. Comp. Neurol. 296: 1-22.

Xie, W., Chow, L.T., Paterson, A.J., Chin, E., and Kudlow, J.E. 1999. Conditional expression of the ErbB2 oncogene elicits reversible hyperplasia in stratified epithelia and up-regulation of TGF $\alpha$ expression in transgenic mice. Oncogene 18: 3593-3607.

Ye, P., Popken, G.J., Kemper, A., McCarthy, K., Popko, B., and D'Ercole, A.J. 2004. Astrocyte-specific overexpression of insulin-like growth factor-I promotes brain overgrowth and glial fibrillary acidic protein expression. J. Neurosci. Res. 78: 472-484.

Yiu, G. and He, Z. 2006. Glial inhibition of CNS axon regeneration. Nat. Rev. Neurosci. 7: 617-627.

Yoon, K., Nery, S., Rutlin, M.L., Radtke, F., Fishell, G., and Gaiano, N. 2004. Fibroblast growth factor receptor signaling promotes radial glial identity and interacts with Notch1 signaling in telencephalic progenitors. J. Neurosci. 24: 9497-9506. 


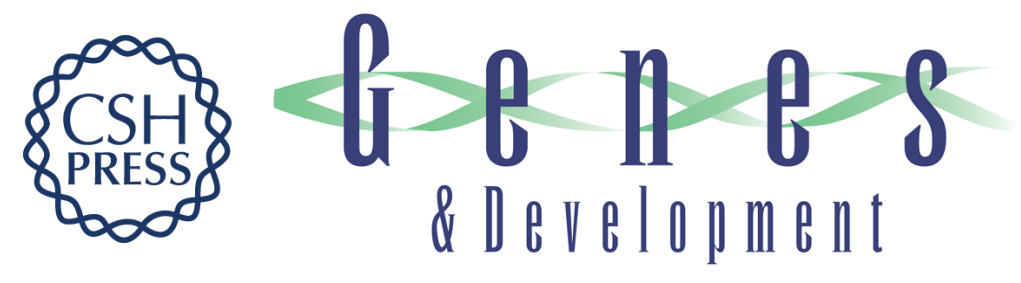

\section{Reinduction of ErbB2 in astrocytes promotes radial glial progenitor identity in adult cerebral cortex}

H.T. Ghashghaei, Jill M. Weimer, Ralf S. Schmid, et al.

Genes Dev. 2007, 21:

Access the most recent version at doi:10.1101/gad.1580407

Supplemental http://genesdev.cshlp.org/content/suppl/2007/11/28/21.24.3258.DC1
Material

References This article cites 87 articles, 25 of which can be accessed free at:

http://genesdev.cshlp.org/content/21/24/3258.full.html\#ref-list-1

License

Email Alerting

Receive free email alerts when new articles cite this article - sign up in the box at the top

Service

right corner of the article or click here.

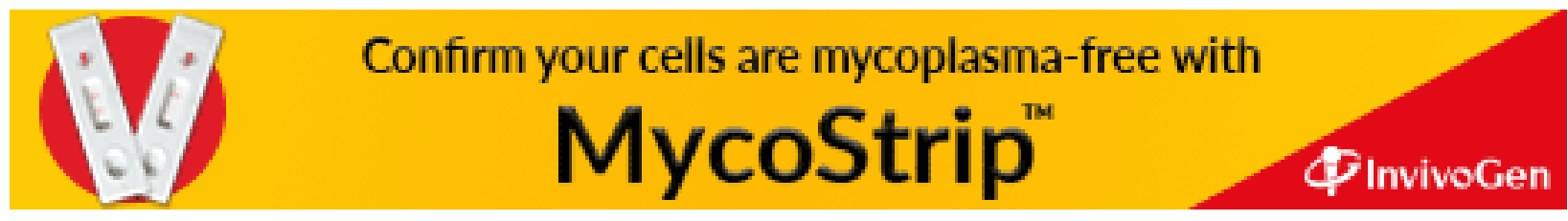

